\title{
PENGEMBANGAN PERANGKAT PEMBELAJARAN FISIKA MODEL INKUIRI TERBIMBING UNTUK MELATIHKAN KINERJA ILMIAH SISWA
}

\author{
Dian Pradianti' ${ }^{1)}$, Wasis ${ }^{2)}$, Rudiana Agustini ${ }^{3)}$ \\ ${ }^{1)}$ Program Studi Pendidikan Dasar, Program Pascasarjana Universitas Negeri Surabaya \\ ${ }^{2), 3)}$ Dosen Pascasarjana Prodi Pendidikan Sains Univesrtitas Negeri Surabaya \\ E-mail: dianze83@gmail.com
}

\begin{abstract}
This research aims to produce physics teaching material through guided inquiry model which is valid, practical, and effective to facilitate the students' scientific skill in senior high school. The development of teaching material used the Kemp model and was tested in class X MIA of SMAN 1 Pasir Belengkong first semester in academic year 2014/2015 by using the onegroup pretest-posttest design. The data collection used Validation, observation, tets, and questionnaire student responses. The data analysis techniques used quantitativ and qualitativ descriptive analysis. The results of this research are:1) Teaching material developed has a valid category; 2) The practicality of teaching material in terms of a good category in feasibility of lesson plans and the students' activities in accordance with steps of guided inquiry model; and 3) The teaching material effectiveness in terms of: (a) Improving students' learning achievement seen with high gain scores; (b) Percentage of scientific skill of students indicated by the increased of each meeting; and (c) The students'responds toward material and implementation of learning are positive. Based on the result of the above It's conclusion that the teaching material through guided inquiry model are valid, practical, and effective so that used to facilitate the students scientific skill in senior high school.
\end{abstract}

Keywords: Development of learning material, guided inquiry, scientific skill

\begin{abstract}
Abstrak: Penelitian ini bertujuan untuk menghasilkan perangkat pembelajaran fisika model inkuiri terbimbing yang valid, praktis, dan efektif untuk melatihkan kinerja ilmiah siswa SMA. Pengembangan perangkat pembelajaran menggunakan model Kemp dan diujicobakan di kelas X MIA SMAN 1 Pasir Belenkong semester genap tahun ajaran 2014/2015 dengan one-group pretest-posttest design. Pengumpulan data menggunakan metode validasi, observasi, tes, dan angket respon siswa. Teknik analisis data menggunakan analisis kuantitatif dan deskriptip kualitatif. Temuan hasil penelitian, yaitu: 1) Perangkat pembelajaran yang dikembangkan berkategori valid; 2) Kepraktisan perangkat pembelajaran ditinjau dari keterlaksanaan RPP berkategori baik dan aktivitas siswa sesuai dengan tahap-tahap pada model inkuiri terbimbing; dan 3) Keefektifan perangkat pembelajaran ditinjau dari: (a) Peningkatan hasil belajar siswa rata-rata tinggi; (b) Persentase kinerja ilmiah siswa ditunjukkan dengan meningkatnya setiap pertemuannya; dan (c) Respon siswa terhadap perangkat dan pelaksanaan pembelajaran positif. Berdasarkan hasil-hasil di atas disimpulkan bahwa perangkat pembelajaran model inkuiri terbimbing yang dikembangkan valid, praktis, dan efektif sehingga layak digunakan untuk melatihkan kinerja ilmiah siswa SMA.
\end{abstract}

Kata kunci: Perangkat Pembelajaran, Inkuiri Terbimbing, Kinerja Ilmiah.

\section{PENDAhuluan}

Negara Indonesia dalam mewujudkan cita-cita mencerdaskan kehidupan bangsa, serta sejalan dengan visi dan misi pendidikan nasional, Kemendiknas merumuskan visi 2025 yaitu menghasilkan insan Indonesia cerdas dan kompetitif. Insan Indonesia cerdas yang dimaksud adalah insan yang komprehensip, yaitu cerdas spiritual, cerdas emosioanl, cerdas sosial, cerdas intelektual, dan cerdas kinestetis (Mulyasa, 2013)

Mencerdaskan kehidupan bangsa dan mengembangkan kualitas manusia seutuhnya adalah misi pendidikan yang menjadi tanggung jawab profesional setiap guru. Pengembangan kualitas manusia ini menjadi suatu keharusan, terutama dalam memasuki era negara globalisasi dewasa ini diperlukan pengetahuan dan keanekaragaman keterampilan agar siswa mampu memperdayakan dirinya untuk menemukan, menafsirkan, menilai dan menggunakan informasi serta melahirkan gagasan kreatif untuk menentukan sikap dalam pengambilan keputusan.

Pendidikan adalah salah satu wahana untuk meningkatkan kualitas sumber daya manusia. Menurut Undang-undang No. 20 Tahun 2003 Tentang Sistem Pendidikan Nasional (UU Sisdiknas 2003), menyatakan "Pendidikan merupakan usaha sadar dan terencana untuk mewujudkan suasana belajar dan proses pembelajaran agar siswa secara aktif mengembangkan potensi dirinya untuk memiliki kekuatan spiritual keagamaan, pengendalian diri, kepribadian, kecerdasan, akhlak mulia, serta keterampilan yang diperlukan dirinya, masyarakat, bangsa dan negara".

Peranan guru sebagai pengajar sangat penting supaya tujuan di atas dapat tercapai, hendaknya guru dapat menyajikan materi dengan baik dan siswa 
dilibatkan dalam proses belajar mengajar dan dibutuhkan pemahaman terhadap subjek didik guna penyelenggaraan proses pembelajaran yang baik. Proses pembelajaran sebagai inti pendidikan merupakan proses yang kompleks karena melibatkan berbagai faktor yang harus dirancang dengan baik guna terbangun keharmonisan dalam sistem pembelajaran dengan tujuan yang diidamkan akan tercapai melalui proses pembelajaran yang menyenangkan.

Pembelajaran IPA salah satu cabangnya adalah pembelajaran fisika yang diharapkan dapat menjadi wahana bagi peserta didik untuk mempelajari diri sendiri dan alam sekitar, serta prospek pengembangan lebih lanjut dalam menerapkannya di dalam kehidupan sehari-hari. Dengan demikian hakikat pembelajaran IPA (Fisika) adalah proses, produk dan sikap. Pembelajaran fisika di sekolah tidak hanya mementingkan penguasaan konsep fisika terhadap fakta konsep dan teori IPA (sebagai produk) tetapi yang lebih penting adalah siswa mengerti proses bagaimana fakta dan teori-teori tersebut ditemukan. Dengan kata lain siswa harus mendapat pengalaman langsung dan menemukan sendiri proses tersebut (Depdiknas, 2006).

IPA sebagai proses dapat diperlihatkan melalui kinerja ilmiah, namun berdasarkan pengalaman peneliti sebagai guru selama 5 tahun di SMAN 1 Pasir Belengkong dan hasil diskusi yang telah dilakukan dengan guru fisika pada awal Maret 2014 memperlihatkan nilai kinerja ilmiah siswa masih jauh dari harapan. Hampir keseluruhan siswa kelas X MIA sebanyak $75 \%$ dalam kegiatan praktikum yang dilakukan belum mampumelatihkan kinerja ilmiah, padahal siswa sudah diberi kesempatan untuk bertanya dan mengemukakan idenya secara individu maupun berkelompok tetapi siswa cenderung pasif sehingga guru terpaksa lebih banyak mendominasi pembelajaran.

Hasil observasi melalui wawancara pada siswa dan guru ditemukan beberapa penyebab belum terlaksana secara maksimal dalam upaya melatihkan kinerja ilmiah siswa pembelajaran fisika, yaitu: (1) Keterbatasan waktu guru mata pelajaran fisika untuk dapat menyediakan perangkat pembelajaran untuk melatih kinerja ilmiah siswa (2) Guru bidang studi fisika kesulitan menangani siswa dengan kemampuan rendah dapat aktif dan termotivasi belajar fisika, selain itu kegiatan praktikum yang merupakan kegiatan ilmiah yang mampu menumbuhkan kinerja ilmiah masih jarang dilakukan karena keterbatasan alat dan belum adanya perangkat pembelajaran yang memperhatikan aspek kinerja ilmiah sebagai indikator tujuan pembelajaran sehingga sering mengutamakan konsep kognitif saja sebagai tujuan pembelajaran.

Kenyataan ini didukung oleh penelitian-penelitian yang menyatakan bahwa dalam proses pembelajaran masih kurang adanya pemberdayaan kemampuan berpikir siswa dan mengarahkan siswa untuk bekerja secara lmiah. Secara terpisah beberapa penelitian menunjukkan bahwa kurangnya peningkatan kinerja ilmiah yang dilakukan oleh siswa dapat dilihat berdasarkan hasil penelitian yang dilakukan sadia dkk (dalam Sutama dkk, 2014) menunjukkan bahwa 95\% tujuan pembelajaran khusus (TPK) yang dirancang guru sains SMU di Kabupaten Buleleng mengarah pada penguasaan produk sains dan hanya $5 \%$ yang mengarah pada kinerja ilmiah. Di sisi lain, ujian nasional yang selalu dimonopoli oleh produk sains dan mengabaikan proses sains menyebabkan rendahnya kemampuan siswa untuk mengeksplorasi kemampuannya dalam kinerja ilmiah.

Keterampilan proses yang merupakan bagian dari kinerja ilmiah yang mengarah pada proses penemuan belum mendapat perhatian yang serius dalam pendidikan. Suastra dalam sutama (2014) mengungkapkan bahwa pencapaian kinerja ilmiah siswa yang masih rendah dalam pembelajaran disebabkan karena materi yang terlalu padat dan tolak ukur keberhasilan pendidikan di sekolah masih difokuskan dari segi produk (konsep). Kunandar dalam Sutama (2014) juga menyatakan bahwa pembelajaran harus lebih menekankan pada praktik baik di laboratorium maupun di masyarakat yang mengacu pada kemampuan kinerja ilmiah, dengan demikian pentingnya kinerja ilmiah tersebut seyogyanya kegiatan pembelajaran di kelas menekankan kinerja ilmiah.

Kurikulum 2013 yang berbasis karakter dan kompetensi, salah satunya adalah mengubah pola pendidikan dari orientasi terhadap hasil dan materi ke pendidikan sebagai proses, melalui pendekatan tematik integratif dengan Contextual teaching and learning (CTL). Pembelajaran harus sebanyak mungkin melibatkan siswa, agar siswa mampu bereksplorasi untuk membentuk kompetensi dengan menggali berbagai potensi dan kebenaran secara ilmiah. kerangka inilah perlunya kreativitas guru agar siswa mampu menjadi fasilitator, dan mitra belajar sehingga guru tidak hanya menyampaikan informasi materi pelajaran kepada siswa (Mulyasa, 2013).

Berdasarkan uraian di atas, perlu adanya model pembelajaran yang dapat digunakan oleh guru dalam mengolah pembelajaran yang berpusat pada siswa, yang memberikan solusi dalam meningkatkan kinerja ilmiah siswa, salah satunya melalui inquiry. Model Pembelajaran inquiry merupakan proses berpikir yang diawali dengan pengamatan. Inquiry merupakan suatu proses berpikir yang ditempuh siswa untuk menemukan suatu konsep melalui langkah perumusan masalah, pengajuan hipotesis, merencanakan pengujian hipotesis, melakukan pengujian hipotesis melalui eksperimen dan 
demonstrasi, mencatat data hasil eksperimen, mengolah data, menganalisis data dan membuat kesimpulan (Wena, 2009).

Penggunaan model pembelajaran inquiry dalam pembelajaran fisika di tingkat sekolah telah banyak dilakukan, menurut hasil penelitian rozi (2011) menemukan bahwa inkuiri terbimbing lebih efektif dalam pemahaman konsep ditinjau dari kerja ilmiah daripada pembelajaran dengan menggunakan structured inquiry. Pembelajaran inquiry dianggap dapat menanamkan pemahaman dan pengertian serta membimbing siswa agar mampu memahami konsep dan prinsip fisika. Pembelajaran inquiry juga mampu mengembangkan kemampuan berpikir dan memecahkan masalah siswa sehingga dengan sendirinya siswa itu dapat menemukan bagaimana konsep itu terbentuk (Nur, 2008).

Berdasarkan uraian di atas, peneliti melakukan penelitian dengan judul "Pengembangan Perangkat Pembelajaran Fisika Model Inkuiri Terbimbing Untuk Melatihkan Kinerja Ilmiah Siswa". Perangkat yang dikembangkan meliputi : Rencana Pelaksanaan Pembelajaran (RPP), Buku Ajar Siswa (BAS), Lembar Kerja Siswa (LKS), dan Instrumen Evaluasi.

Secara umum, tujuan penelitian ini adalah untuk menghasilkan perangkat pembelajaran fisika model inkuiri terbimbing yang valid, praktis, dan efektif untuk melatihkan kinerja ilmiah siswa SMA.

\section{METODE PENELITIAN}

\section{A. Jenis Penelitian}

Jenis Penelitian ini adalah penelitian pengembangan. Perangkat pembelajaran yang dikembangkan terdiri dari Rencana Pelaksanaan Pembelajaran (RPP), Lembar Kegiatan Siswa (LKS), Buku Ajar Siswa (BAS), dan Tes Hasil Belajar, dan Tes Kinerja (Kinerja Ilmiah).

\section{B. Tempat dan Waktu Pembelajaran}

Penelitian ini dilaksanakan di SMA Negeri 1 Pasir Belengkong semester ganjil tahun pelajaran 2014-2015.

\section{Subjek Penelitian}

Subjek penelitian adalah perangkat pembelajara Fisika mengacu pada medel pembelajaran inkuiri terbimbing pada materi pokok fluida statis yang diterapkan pada 27 siswa.

\section{Prosedur Penelitian}

Model pengembangan perangkat yang digunakan dalam penelitian ini mengacu pada model Kemp (2011). Pengembangan perangkat pembelajaran merupakan suatu lingkaran yang kontinu. Model ini dipilih karena setiap tahap yang diikuti lebih sistematis, memberikan acuan yang cukup jelas dalam mendesain perangkat pembelajaran, tiap-tiap langkah pengembangan berhubungan langsung dengan aktivitas revisi, dan setiap pengembang (designer) bisa memulai dari langkah yang berbeda sesuai kebutuhan.Tahapan pengembangan perangkat pembelajaran dapat dilihat pada Gambar 1

\section{E. Rancangan Penelitian Penelitian}

Rancangan uji coba perangkat pembelajaran yang digunakan adalah One Group Pretest - Posttest Design (Arikunto, 2010). Rancangan uji coba perangkat dapat digambarkan sebagai berikut:

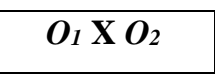

Dengan:

$\mathrm{O}_{1}$ : Uji Awal, untuk mengetahui tingkat penguasaan siswa terhadap materi pembelajaran sebelum dengan perlakuan (pretest).

$\mathrm{X}$ : Memberikan perlakuan pada siswa, yaitu pembelajaran dengan model inkuiri terbimbing untuk melatihkan keterampilan proses sains siswa

$\mathrm{O}_{2}$ : Uji Akhir, untuk mengetahui hasil belajar dan tingkat penguasan materi pembelajaran sesudah perlakuan (posttest

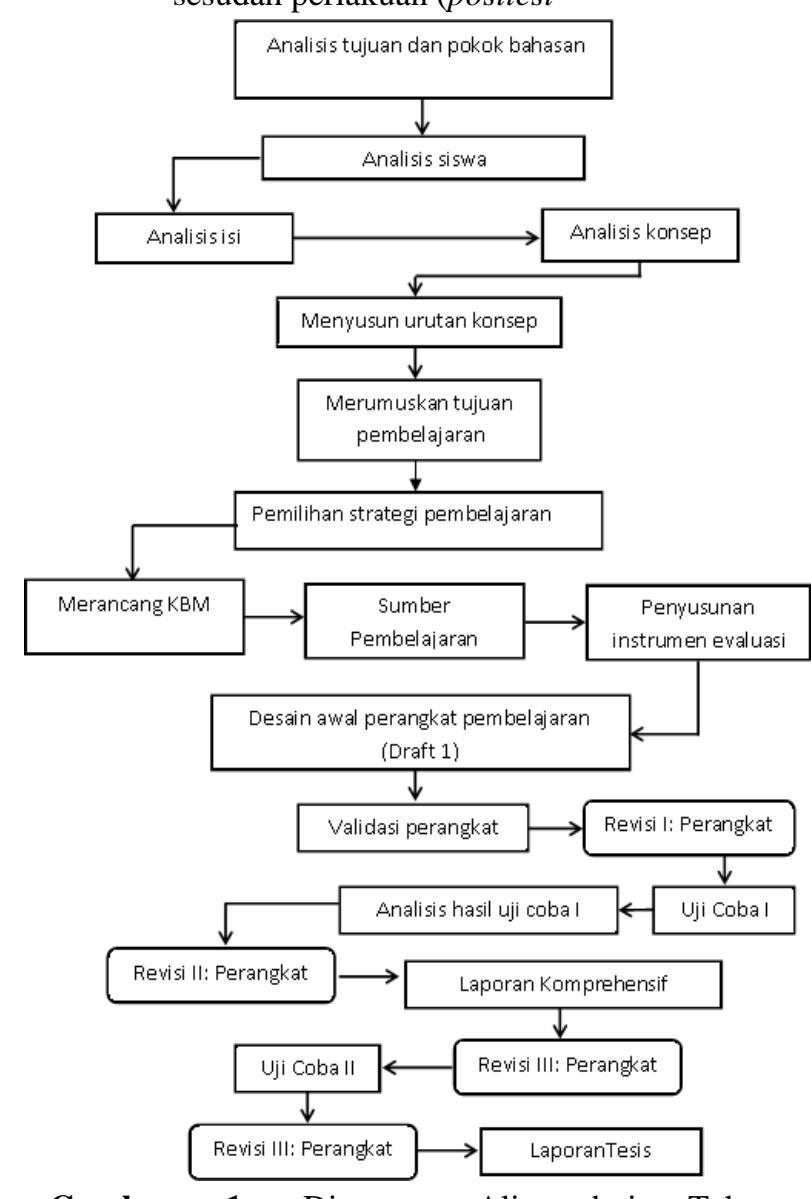

Gambar 1. Diagram Alir dari Tahapan Pengembangan Perangkat Pembelajaran 
Teknik pengumpulan data digunakan untuk memperoleh bahan-bahan yang relevan, akurat, dan dapat digunakan dengan tepat sesuai tujuan penelitian. Teknik pengumpulan data yang digunakan dalam penelitian ini adalah: (1)Validasi; (2) observasi; (3) angket; dan (4) pemberian tes.

\section{F. Teknik Analisis Data}

Analisis data yang digunakan dalam penelitian ini adalah:

1. Analisis validitas Peragkat Pembelajaran

Perangkat pembelajaran yang dikembangkan selanjutnya ditelaah oleh pembimbing dan di validasi oleh validator. Data yang diperoleh dianalisis kuantitatif dan deskriptif kualitatif. Hasil penskoran di deskripsikan sebagai berikut:

Tabel 1. Kriteria Pengkategorian Penilaian Validasi Perangkat Pembelajaran

\begin{tabular}{|l|l|}
\hline \multicolumn{1}{|c|}{ Interval Skor } & \multicolumn{1}{c|}{ Kategori Penilaian } \\
\hline $3,5 \leq \mathrm{P} \leq 4,0$ & Baik / Valid \\
\hline $2,5 \leq \mathrm{P}<3,5$ & Cukup Baik / Cukup Valid \\
\hline $1,5 \leq \mathrm{P}<2,5$ & Kurang Baik/ Kurang Valid \\
\hline $1,0 \leq \mathrm{P}<1,5$ & Tidak Baik/ Tidak Valid \\
& \\
\hline
\end{tabular}

(Diadaptasi dari Ratumanan \& Laurens, 2006)

\section{Analisis keterlaksanaan RPP}

Penilaian dan pengamatan dilakukan setiap kali tatap muka oleh dua orang pengamat. Teknik analisis data keterlaksanaan RPP dilakukan secara deskriptif kuantitatif dengan teknik persentase sebagai berikut:

$$
\mathrm{P}=\frac{\Sigma \mathrm{A}}{\Sigma \mathrm{N}} \times 100 \%
$$

Keterangan:

P : Persentase keterlaksanaan RPP

$\Sigma$ A : Jumlah aspek yang terlaksana

$\Sigma \mathrm{N}$ : Jumlah keseluruhan aspek yang diamati

Hasil pengamatan keterlaksanaan pembelajaran dianalisis dengan menggunakan analisis deskriptif kualitatif dengan cara menghitung hasil pengamatan, dihitung berdasarkan skor rata-rata tiap bagian untuk tiap RPP dan dikonversi menggunakan kriteria sebagai berikut:

$$
\begin{array}{lll}
1,00-1,99 & = & \text { tidak baik } \\
2,00-2,99 & = & \text { kurang baik } \\
3,00-3,49 & = & \text { cukup baik } \\
3,50-4,00 & = & \text { baik }
\end{array}
$$

(Diadaptasi dari Ratumanan \& Laurens, 2006)
3. Analisis Pengamatan Aktivitas Siswa

Aktivitas siswa adalah segala aktivitas yang dilakukan oleh siswa selama KBM berlangsung dan dinilai oleh dua pengamat dengan menggunakan instrumen yang disediakan. Data yang diperoleh dipersentasekan menggunakan rumus sebagai berikut:

$$
\mathrm{P}=\frac{\mathrm{R}}{\mathrm{N}} \times 100 \%
$$

Keterangan:

P: Jumlah nilai dalam persen

F : Frekuensi dalam menit aktivitas siswa yang diamati

$\mathrm{N}$ : Jumlah aktivitas keseluruhan dalam menit

(Arifin, 2009)

4. Analisis Aspek Pengetahuan

a. Analisis $N$-Gain

Data hasil pretest dan posttest siswa dianalisis peningkatan $N$-Gain dengan persamaan dibawah ini.

Keterangan:

$$
\langle\mathrm{g}\rangle=\frac{S_{\text {post }}-S_{\text {pret }}}{S_{\text {max }}-S_{\text {pret }}}
$$

$$
\begin{aligned}
\langle\mathrm{g}\rangle & =\text { nilai gain } \\
S_{\text {pret }} & =\text { nilai pre-test } \\
S_{\text {post }} & =\text { nilai post-test } \\
S_{\text {max }} & =\text { nilai maksimal }
\end{aligned}
$$

Tabel 2. Kriteria Normalized Gain

\begin{tabular}{|l|c|}
\hline Skor $N$-Gain & $\begin{array}{c}\text { Kriteria Normalized } \\
\text { Gain }\end{array}$ \\
\hline $0.70<N$-Gain & Tinggi \\
\hline $0.30 \leq N$-Gain $\leq 0.70$ & Sedang \\
\hline$N$-Gain $<0.30$ & Rendah \\
\hline
\end{tabular}

(Hake,1999)

b. Sensitivitas Soal berikut:

Sensitivitas soal digunakan rumus sebagai

$$
\text { Sensitivitas Soal }=\frac{R_{a}-R_{b}}{T}
$$

\section{Keterangan:}

$$
\begin{aligned}
& \mathrm{Ra}=\text { Banyaknya siswa yang menjawab benar } \\
& \text { pada tes akhir } \\
& \mathrm{Rb}=\text { Banyaknya siswa yang menjawab benar } \\
& \text { pada tes awal } \\
& \mathrm{T}=\text { Banyaknya siswa yang mengikuti tes }
\end{aligned}
$$

(Gronlund \& Linn, 1995)

\section{Analisis Kinerja Ilmiah Siswa}

Ketuntasan tes kinerja ini merujuk pada KKM yaitu lebih besar atau sama dengan 75 . Ketuntasan tes kinerja dapat dihitung dengan menggunakan persamaan sebagai berikut: 


$$
\mathrm{KI}=\frac{\text { jumlah skor yang diperoleh }}{\text { jumlah skor maksimum }} \times 100 \%
$$

Keterangan: $\mathrm{KI}=$ Kinerja Ilmiah

\section{Analisis Respon Siswa}

Angket respon siswa digunakan untuk mengetahui pendapat siswa terhadap penerapan perangkat pembelajaran yang dikembangkan. Respon siswa dianalisis secara deskriptif dengan rumus persentase sebagai berikut:

Keterangan:

$$
\mathrm{P}=\frac{\Sigma \mathrm{R}}{\Sigma \mathrm{N}} \times 100 \%
$$

\section{$\mathrm{P}:$ Persentase respon siswa \\ $\Sigma$ R: Jumlah respon \\ $\Sigma \mathrm{N}$ : Jumlah keseluruhan respon}

(Riduwan, 2010)

7. Analisis Kendala-kendala selama Kegiatan Belajar Mengajar

Data yang diperoleh dari lembar pengamatan kendala atau hambatan yang ditemui dilapangan selama KBM dideskripsikan dan dicari solusinya untuk memperbaiki kendala-kendala yang ditemukan.

\section{HASIL PENELITIAN DAN DISKUSI}

A. Hasil Pengembangan Perangkat Pembelajaran

Hasil pengembangan perangkat pembelajaran fisika model inkuiri terbimbing yang dikembangkan valid untuk digunakan dalam pembelajaran fisika untuk melatihkan kinerja ilmiah.

\section{Keterlaksanaan RPP}

Hasil pengembangan perangkat pembelajaran yang dikembangkan telah praktis untuk digunakan. Hasil pengamatan keterlaksanaan RPP yang dilakukan oleh dua orang guru mata pelajaran fisika disajikan pada Gambar 2

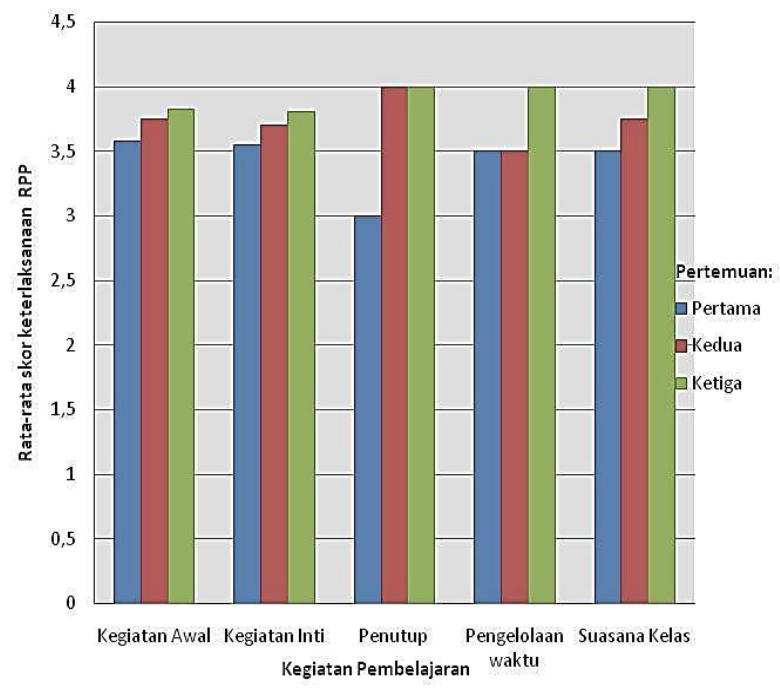

Gambar 2. Keterlaksanaan RPP
Pengamatan kegiatan belajar mengajar (KBM) pada tahap pendahuluan; merupakan tahap pertama dalam model pembelajaran inkuiri terbimbing, Guru secara aktif memotivasi siswa untuk fokus dalam kegiatan belajar mengajar, yang dapat terlihat dari hasil pengamatan pada antusias guru dan siswa di dalam kelas yang menunjukkan rata-rata keterlaksanaan pembelajaran dengan kategori baik. Guru berhasil dalam membimbig siswa untuk menyiapkan dalam kegiatan penyelidikan dan siswa aktif berpartisipasi dalam pembelajaran. Hal ini sesuai dengan teori Bruner tentang belajar penemuan yang menyarankan agar siswa hendaknya belajar melalui partisipasi secara aktif dengan konsep-konsep dan prinsip-prinsip, agar siswa memperoleh pengalaman, dan melakukan eksperimeneksperimen yang mengizinkan siswa menemukan prinsip-prinsip siswa tersebut (Slavin, 2011).

Tahap kegiatan inti terdapat di dalamnya tahapan pembelajaran inkuiri terbimbing yaitu tahap perumusan hipotesis, tahap pengumpulan data melalui percobaan, tahap pengolahan data, tahap analisis proses inkuiri,penarikan kesimpulan dan menyajikan hasil percobaan. Pada tahap ini guru perlu memberikan perhatian lebih dalam membimbing siswa melakukan praktikum. Seorang guru jika tidak memberikan scaffolding kepada siswa akan menyebabkan kecenderungan melakukan kegiatan di luar pembelajaran, karena itu, guru perlu membimbing siswa ketika mulai merekonstruksi penjelasan mereka pada kegiatan tersebut (Mercer, 2004). Guru memberikan bimbingan kepada siswa agar dapat membuat siswa mencapai zone of proximal development (ZPD). Tugastugas dalam zona perkembangan proksimal adalah sesuatu yang masih belum dapat dikerjakan anak sendirian tetapi dapat dikerjakan dengan bantuan teman yang lebih kompeten atau orang dewasa (Slavin, 2011).

Hasil skor rata-rata pengelolahan waktu dan aspek suasana kelas mengindikasikan terjadi peningkatan yang signifikan selama pembelajaran. Hal ini diperkuat dari hasil observasi langsung ke siswa saat pelaksanaan pembelajaran bahwa siswa senang karena merasa lebih bisa aktif untuk mendapatkan konsep yang bermakna ketika belajar fisika dengan kegiatan percobaan. John Dewey menggambarkan pembelajaran sebagai proses aktif individu, bukan sesuatu dilakukan untuk seseorang tetapi lebih kepada sesuatu itu dilakukan oleh seseorang dan menganggap bahwa pengalaman dan inkuiri (penyelidikan) sangat penting dalam pembelajaran bermakna (Kuhlthau dan Todd, 2008).

\section{Aktivitas Siswa}

Aktivitas siswa selama proses pembelajaran yang diamati oleh dua orang guru mata pelajaran fisika disajikan pada Gambar 3. 


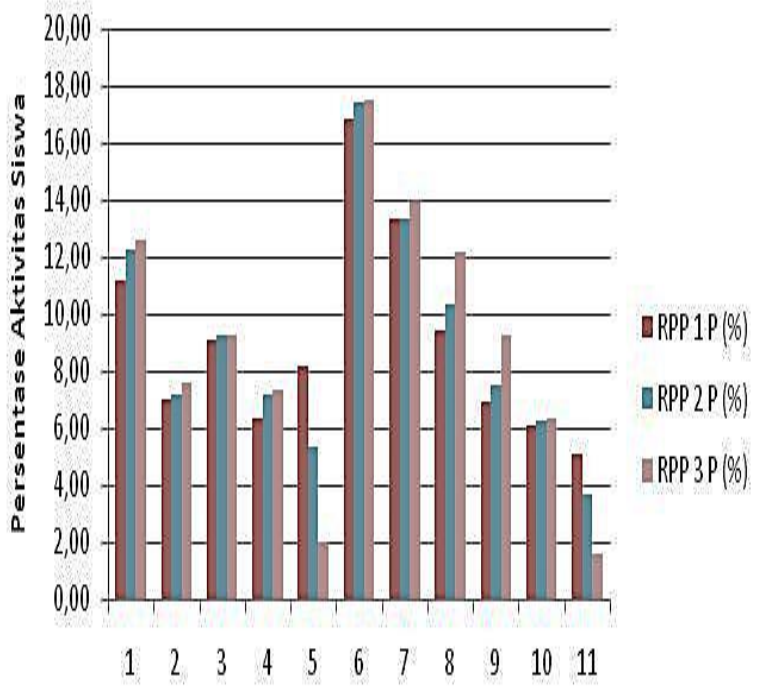

Aktivitas Siswa

Gambar 3. Aktivitas Siswa

Keterangan:

1. Memperhatikan penjelasan guru

2. Menjawab pertanyaan guru

3. Merumuskan hipotesis

4. Menentukan variabel percobaan

5. Bertanya kepada guru

6. Merancang, melakukan dan menuliskan langkah-langkah percobaan

7. Menganalisis data percobaan

8. Membuat Kesimpulan

9. Menyajikan dan mengkomunikasikan hasil percobaan

10. Menjawab dan menanggapi penyajian kelompok lain

11. Perilaku tidak relevan

Aktivitas siswa rata-rata tiap pertemuan mengalami peningkatan, hal ini menunjukkan bahwa siswa dalam kegiatan pembelajaran berada di lingkungan sosial, mereka terus menerus belajar melalui interaksi dengan orang lain di sekitar mereka. Vigotsky berpendapat bahwa perkembangan proses hidup bergantung pada interaksi sosial dan pembelajaran sosial berperan penting untuk perkembangan kognitif (Khulthau \& Todd, 2008). Aktivitas siswa menggunakan model inkuri terbimbing untuk melatihkan kinerja ilmiah siswa, ada empat aktivitas yang menonjol adalah memperhatikan penjelasan guru, merancang, melakukan dan menuliskan langkahlangkah percobaan, menganalisis data, dan membuat kesimpulan, Pada aktivitas. memperhatikan penjelasan guru dengan persentase $11.23 \%, 12.27 \%$, dan $12.63 \%$ menunjukkan bahwa guru masih berperan dalam kegiatan pembelajaran karena masih ada kelompok kurang percaya diri dalam menyelesaikan kegiatan LKS. Siswa masih belum bisa dilepas secara penuh karena belum terbiasa dalam pembelajaran fisika kegiatan penyelidikan di laboratorium. Peranan guru dalam pembelajaran inkuiri terbimbing menjadi fasilitator dan membimbing siswa yang masih kesulitan dalam melakukan penyelidikan. Guru melalui inkuiri terbimbing, pada awalnya harus memantau gagasan ide kelas dan ketika siswa mengembangkan gagasan idenya (Minstrell dan Kraus, 2005).

Aktivitas siswa dalam bertanya kepada guru saat eksperimen tentang prosedur percobaan dan melakukan aktivitas yang tidak relevan dari pertemuan pertama sampai ketiga mengalami penurunan yang signifikan. Peranan guru dalam pembelajaran inkuiri terbimbing menjadi fasilitator dan membimbing siswa yang masih kesulitan dalam melakukan penyelidikan. Minstrell \& Kraus (2005) menyatakan bahwa inkuiri terbimbing pada awalnya guru harus memantau gagasan ide kelas dan ketika mereka mengembangkan, ada beberapa siswa masih belum bisa dilepas secara penuh karena belum terbiasa dalam pembelajaran fisika kegiatan penyelidikan di laboratorium.

3. Hasil Belajar Aspek Pengetahuan

Hasil belajar ketuntasan tujuan indikator pembelajaran aspek pengetahuan pada post-test sebesar 82.6.\%. Pada post test atau setelah diterapkannya model inkuiri terbimbing, baik jumlah siswa yang dinyatakan tuntas secara individu dan klasikal mengalami peningkatan dengan persentase ketuntasan klasikal adalah 92.6 \%. Hasil analisis Normalized Gain menunjukkan bahwa siswa yang mengalami peningkatan hasil belajar dan masuk dalam kriteria tinggi sebesar $66.7 \%$ dan kategori sedang sebesar 33.3 $\%$ (Hake, 1999). Peningkatan yang ditunjukkan oleh hasil analisis dengan menggunakan $N$-Gain ini menunjukkan tentang penerapan dari pengembangan perangkat pembelajaran fisika model inkuiri terbimbing efektif dalam meningkatkan penguasaan aspek pengetahuan pada materi fluida statis.

Sensitivitas butir soal digunakan untuk mengetahui apakah soal yang dikembangkan baik atau tidak, dapat dilihat dari tingkat sensitivitas tiap butir soal. Hasil analisis diperoleh bahwa semua soal penguasaan pengetahuan yang dikembangkan mendapat nilai di atas 0.30 maka dinyatakan sensitiv (Gronlund dan Linn, 1995) artinya bahwa butir soal yang diujikan peka terhadap efek-efek pembelajaran fisika dengan model inkuiri terbimbing untuk melatihkan kinerja ilmiah

\section{Keterampilan Kinerja Ilmiah}

Hasil belajar aspek keterampilan kinerja ilmiah siswa dapat dilihat pada Gambar 4 


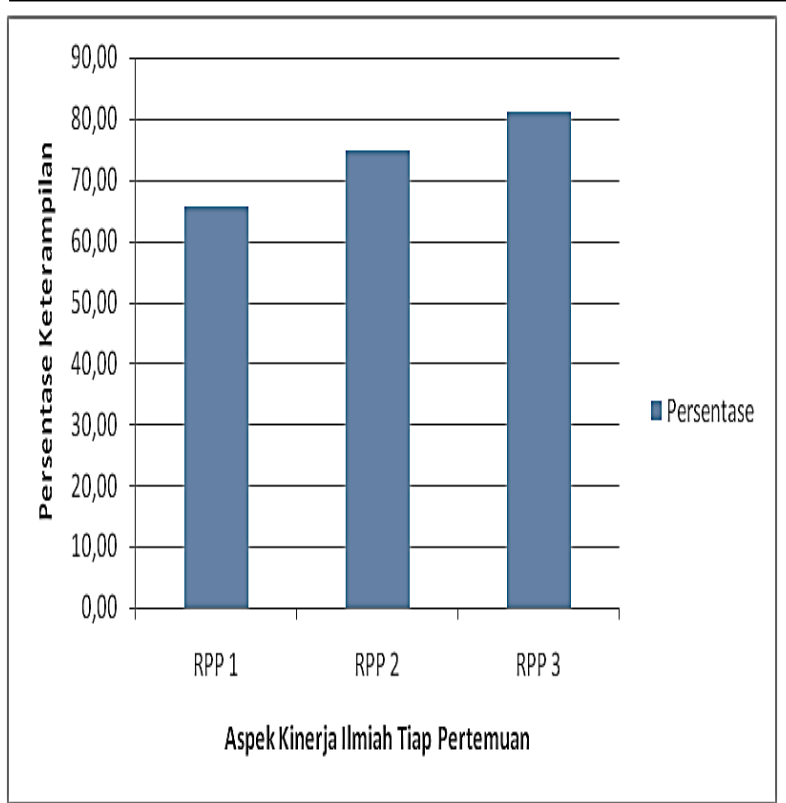

Gambar 4. Aspek kinerja ilmiah

Kinerja ilmiah yang dinilai dalam penelitian ini adalah merumuskan masalah, membuat hipotesis, menentukan variabel percobaan, merancang percobaan, membuat tabel hasil pengamatan, menganalisis data percobaan, dan membuat kesimpulan. Pada Gambar 4.4 selama pembelajaran dengan model inkuri terbimbing siswa menunjukkan peningkatan pada aspek keterampilan kinerja ilmiah di setiap pertemuan, hal ini ditunjukkan dengan meningkatnya persentase di setiap pertemuannya yaitu RPP 1 sebesar $65.55 \%$ RPP 2 sebesar $74.77 \%$ dan RPP 3 sebesar $81.13 \%$. Peneliti beranggapan bahwa hasil ini dicapai karena siswa terus dilatih selama tiga kali pertemuan untuk melakukan kegiatan eksperimen. Pada pertemuan pertama guru memberikan contoh terlebih dahulu bagaimana melakukan eksperimen dan menggunakan keterampilan kinerja. Hal ini dilakukan agar siswa memiliki gambaran-gambaran tentang apa yang akan siswa lakukan saat eksperimen dengan bimbingan guru untuk merumuskan masalah, merumuskan hipotesis, menentukan variabel, merancang, melakukan dan menuliskan langkah-langkah percobaan, membuat tabel data percobaan, menganalisis data, dan membuat kesimpulan.

Secara keseluruhan, berdasarkan hasil ketuntasan tes kinerja ilmiah siswa sudah cukup mampu untuk berlatih kinerja ilmiah melalui tes kinerja. Namun demikian, siswa masih memerlukan latihan secara berkelanjutan agar siswa terbiasa untuk menggunakan kinerja ilmiah dalam memecahkan masalah-masalah pada pembelajaran sains dan hasil belajar yang diharapkan dapat dicapai lebih optimal. Rustaman (2005) menyatakan bahwa model pembelajaran inkuiri yang digunakan oleh guru dapat membuat siswa untuk lebih aktif dalam kegiatan pembelajaran, menanamkan dasar-dasar bekerja ilmiah pada diri siswa, sehingga dalam proses pembelajaran ini siswa lebih banyak aktif dalam memecahkan masalah.

Kinerja ilmiah yang diteliti ini sangat berkaitan erat dengan kurikulum 2013. Kurikulum ini mengamanatkan esensi pendekatan ilmiah dalam pembelajaran. Pendekatan ilmiah diyakini sebagai titian emas perkembangan dan pengembangan sikap, keterampilan, dan pengetahuan siswa. Metode ilmiah umumnya menempatkan fenomena unik dengan kajian spesifik dan detail untuk kemudian merumuskan simpulan umum, untuk dapat disebut ilmiah, metode pencarian (method of inquiry) harus berbasis pada bukti-bukti dari objek yang dapat diobservasi, empiris, dan terukur dengan prinsip-prinsip penalaran yang spesifik, karena itu, metode ilmiah umumnya memuat aktivitas pengoleksian data melalui observasi dan ekperimen, kemudian memformulasi dan menguji hipotesis (Mendikbud, 2013). Rangkaian kegiatan inilah yang dilatihkan oleh peneliti kepada siswa agar mereka terbiasa bekerja ilmiah, khususnya dalam pembelajaran Fisika.

\section{Respon Siswa}

Respon siswa diperoleh dari angket respon yang diberikan kepada siswa setelah diberikan perlakuan menggunakan model pembelajaran inkuiri terbimbing pada materi fluida statis. Pertanyaan di dalam angket siswa secara umum meliputi buku ajar siswa, LKS dan pelaksanaan pembelajaran dengan model inkuiri terbimbing yang dapat dilihat pada Gambar 5.

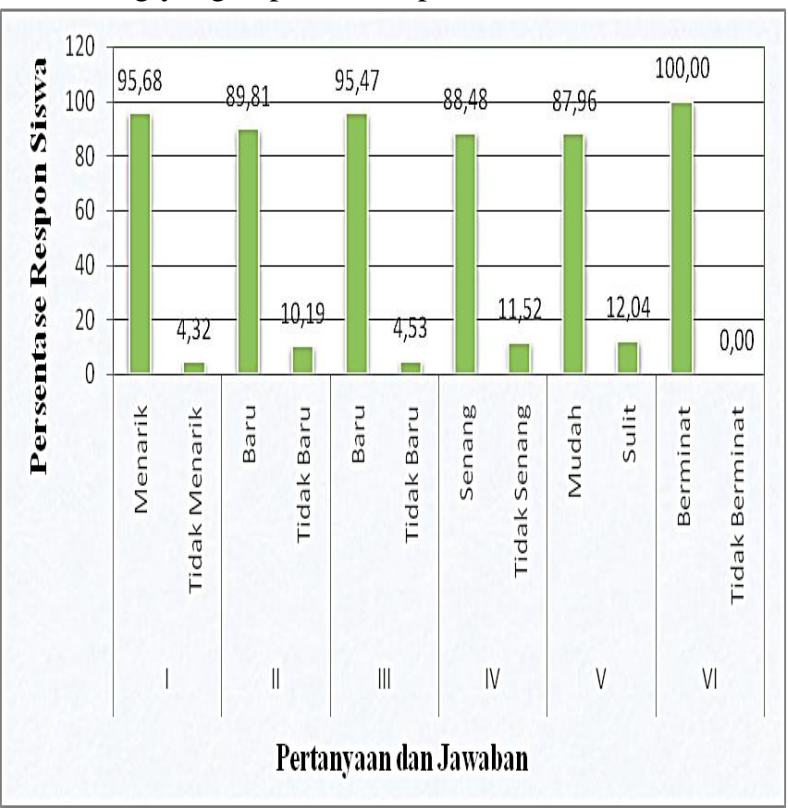

Gambar 5. Respon siswa

Rata-rata respon yang diberikan siswa pada semua item yang dinilai memberikan persentase $\geq 75$, hal ini berarti bahwa sebagian besar memberikan respon yang baik terhadap penerapan perangkat hasil pengembangan 
model inkuiri terbimbing untuk melatihkan kinerja ilmiah siswa. Menurut Arends (2012) studi-studi tentang kelas dan pengajaran menunjukkan bahwa motivasi dan pembelajaran siswa dipengaruhi oleh proses dan struktur yang diciptakan guru di dalam kelas.

Secara umum pelaksanaan pembelajaran dengan menggunakan model inkuiri terbimbing pada materi fluida statis berlangsung dengan baik, akan tetapi terdapat hambatan yang ditemukan dalam pembelajaran

a. Kendala-Kendala

Kendala secara umum adalah memerlukan waktu yang lama untuk membimbing siswa pada tahap kegiatan inti pada pertemuan pertama, karena belum terbiasa praktikum dan mengisi LKS secara mandiri, solusi yang ditawarkan adalah perlunya bimbingan yang lebih intensif yang diberikan guru kepada siswa pada kegiatan inti sehingga waktu yang diperlukan tersebut dapat dimanfaatkan secara efektif.

\section{KESIMPULAN}

\section{A. Simpulan}

Berdasarkan hasil uji coba perangkat, analisis, diskusi, pembahasan, temuan-temuan dalam proses pembelajaran, maka secara umum dapat disimpulkan bahwa perangkat pembelajaran fisika model inkuiri terbimbing yang dikembangkan telah valid, praktis, dan efektif untuk melatihkan kinerja ilmiah siswa.

\section{B. Saran}

Beberapa saran dapat dikemukakan oleh peneliti berdasarkan penelititan yang telah dilakukan adalah sebagai berikut:

1. Penerapan perangkat pembelajaran inkuiri membutuhkan waktu yang lebih lama, maka persiapan dan pengelolaaan waktu perlu mendapat perhatian sehingga pembelajaran dapat dicapai sesuai tujuan yang ditentukan.

2. Peneliti lain perlu melatih siswa untuk lebih mengembangkan kemampuan yang diperlukan pada pembelajaran yang menggunakan kurikulum 2013, yaitu penggunaan keterampilan kinerja ilmiah dalam pembelajaran untuk melakukan kegiatan penyelidikan. Pengenalan awal bisa dilakukan pada waktu khusus, agar saat proses pembelajaran siswa tidak kesulitan menyelesaikan LKS dan melakukan penyelidikan.

\section{REFERENSI}

Arends, R. (2012). Learning To Teach, Ninth Edition. New York: Mc-Graw Hill

Arikunto, S. (2010). Dasar-dasar evaluasi pendidikan. Edisi Revisi. Jakarta: PT. Bumi Aksara.
Arifin, Zaenal. (2009). Evaluasi Pembelajaran. Bandung: PT Remaja Rosda Karya.

Depdiknas. (2006). Peraturan menteri pendidikan nasional republik indonesia no.22 tahun 2006 tentang standar isi untuk satuan pendidikan dasar dan menengah. Jakarta: Dirjen Dikdasmen

Gronlund. E.and Linn, R.L.(1995). Measurement and Assesment in Teaching (7th ed). New Jersey: Merril Englewood Cliffs.

Hake. (1999). Analyzing Change/Gain Scores. (Online). Tersedia http://www. physicsindiana. edu/sdi/ Analyzing-Change-Gain. pdf. Diakses 16 Mei 2013.

Kementerian Pendidikan dan Kebudayaan. (2013). Modul Pelatihan Implementaasi Kurikulum 2013. Jakarta: Badan Pengembangan Sumber Daya Manusia Pendidikan dan Kebudayaan dan Penjaminan Mutu Pendidikan.

Kemp, J.E. (2007). Designing Effective Instruction. New York: Macmillan College Publishing Company.

Khulthau, C.C., \& R.J, Todd. (2008). Guided Inquiry. (Online). Tersedia. icwc.wikispaces.com/file/view/Guided+Inqui ry.doc. Diakses 10 Maret 2013.

Mercer, N., Dawes, L., Wegerif, R. \& Sams, C. (2004). "Reasoning as a Scientist: Ways of Helping Children to Use Language to Learn Science British Educational Research Journal.30 (3), 359-377.

Ministrell, J. and Kraus, P. (2005). "Guided Inquiry in the Scinece Classroom”. In Donovan, M. S and Bransford, J.D. How students learn: history, mathematics, science in the classroom, 475-513. Washington: The National Press.

Mulyasa. (2013). Pengembangan dan Implementasi Kurikulum.Bandung: PT Remaja Rosda Karya.

Nur, M. (2000). Buku Panduan Keterampilan Proses dan Hakekat Sains: PSMS, Unesa, University Press.

Nur, M. Dan Wikandari (2008). Pengajaran Berpusat Kepada Siswa dan Pendekatan Konstruktivisme Dalam Pengajaran: Surabaya: Unesa, University Press.

Ratumanan, G.T., dan T, Laurens. (2006). Evaluasi Hasil yang Relevan dengan Memecahkan Problematika Belajar dan Mengajar. Bandung:CV Alfabeta

Razi. (2013). "Hubungan Motivasi Dengan Kerja Ilmiah Siswa Dalam Pembelajaran Fisika menggunakan Virtual Laboratory Di Kelas X SMAN Kota Padang”. Jurnal Teknologi 
Informasi \& Pendidikan. VoL. 6, No 2. (2013) halaman 121.

Riduwan. (2010). Skala Pengukuran Variabel-Variabel Penelitian. Bandung: Alfabeta.

Rustaman, N. Y. (2005). Perkembangan Penelitian Pembelajaran Berbasis Inkuiri Dalam pembelajaran Sains (Makalah disampaikan dalam Seminar Nasional II di FPMIPA UPI tanggal 22-23 Juli 2005)

Slavin, E. R. (2011). Psikologi Pendidikan : Teori dan Praktik Edisi Kesembila, Jilid I. Jakarta Barat : Indeks.
Sutama, Nyoman. (2014). "Pengaruh Model Pembelajaran Inkuiri Terhadap Keterampilan Berpikir Kritis Dan Kinerja Ilmiah Pada Pelajaran Biologi Kelas XI IPA SMA Negeri 2 Amlapura". e jurnal Program Pascasarjana Universitas Pendidikan Ganesha 4 (2014).

Wena, M. (2009). Strategi Pembelajaran Inovatif Kontemporer. Jakarta: Bumi Aksara 